\title{
Høytflyvende og jordnær
}

\author{
Tomas Nordheim Alme er en nysgjerrig og entusiastisk lege som tar de utfordringene han kan få. \\ Da går det gjerne bra å bli medlem av Indias ekspertgruppe for nyfødtmedisin etter bare halvannet års \\ erfaring fra barneavdeling og være visedirektør for et utviklingsprosjekt i India med en halv milliard \\ i budsjett og FNs tusenårsmål som fokus.
}

Først finner jeg ham ikke. Jeg ringer og finner ut at vi sitter i hver vår ende av lokalet og at han ikke er alene. Tinius på fire og et halvt år er med.

- Når vi er to som jobber mye, må man improvisere, sier han forklarende. Kona Signe er allmennpraktiker og har innimellom lange dager. Tinius har fått et tegneserieblad og virker fornøyd. Trebarnsfaren improviserer og sjonglerer intervju med barnepasta og hjelp til å ordne leken som stadig går i stykker.

Alme er allsidig. De som kjenner ham, beskriver ham som en mann som kan eller lærer seg alt. Han skulle først bli musiker, og spiller fortsatt ved alle slags anledninger. Da han og kona hadde vært gift i 13 år i sommer, overrasket han henne med en selvskrevet sang, spilt inn i studio, der han spilte alle instrumenter, sang og koret selv. Under medisinstudiet lærte han seg å reparere datamaskiner. Han lærte seg mye om IT, startet firma og utviklet programvare for elektronisk pasientjournal (EPJ) til håndholdte datamaskiner. Selskapet ble til slutt kjøpt opp av DIPS, der han fortsatt er medisinsk rådgiver. Etter endt studium fløy han selv hele familien til Korsika i et lite propellfly, og siden kjøpte han seilbåt for å lære seg å seile. Da han hadde jobbet to uker på barneavdeling, ble han spurt om å bli redaktør for Paidos, bladet til Barnelegeforeningen. Der intervjuet han blant annet mange av legene som har formet pediatrifaget i Norge. Slik traff han Sverre O. Lie og ble engasjert i et prosjekt som førte til at hele familien Alme havnet i India.

\section{Tusenårsmål i India}

- Kan du fortelle hva prosjektet i India går ut på?

- Norge ga i 2006500 millioner kroner til Norway India Partnership Initiative, et prosjekt som har fokus på FNs tusenårsmål om barnehelse og relatert mødrehelse. India står for en femdel av barnedødeligheten i verden. Dette prosjektet skal finne nye, bedre og mer hensiktsmessige måter å få levert helsetjenester til barn og mødre. - Hvordan gjør man det?

- Prosjektet var startet før jeg kom, med et sekretariat som besto av indiske eksperter i barnemedisin, folkehelse og administrasjon. Prosjektet har fått tildelt tolv fokusdistrikter, og ett distrikt kan ha 1-3 millioner innbyggere. Vi skulle følge kjeden fra bevilgende myndigheter til nivået hvor tjenesten blir levert til mor og barn, identifisere flaskehalsene for deretter å foreslå løsninger. - Fikk du noen overraskelser?

- Jeg kjente ikke mye til India før jeg kom. Det er nok mye lenger fra Norge enn jeg trodde, også kulturelt sett. Demokratiet er etablert, og har vært det i mer enn 60 år, men like fullt opplevde jeg ikke likeverd som en norm, og for meg blir et demokrati uten grunnleggende likeverd et voldsomt paradoks. Respekten for liv og engasjementet rundt barnedødelighet er langt større i Norge, hvor det dør veldig få barn, enn i India hvor det dør mange barn.

- Ville det av og til vært lettere å levere helsehjelpen selv i stedet?

- Det var aldri et poeng at vi skulle gjøre klinisk arbeid selv. Det er en kortsiktig løsning. Selv om India har et stort underskudd på helsepersonell, er det ikke der det skorter. Utenlandske hjelpeorganisasjoner bør aldri gi varig hjelp, offentlige myndigheter må se det som sin oppgave. Det betyr ikke at hjelpen ikke kan være langsiktig. Likefullt har jeg bilder i hodet av syke babyer jeg har gått forbi, fordi min overfladiske inngripen ville være mest for min egen tilfredsstillelse, og med liten effekt for barnet. Rollen min var å være administrator, ikke lege. Av og til var det fryktelig vanskelig.

\section{Opprørt, men diplomatisk}

\section{- Hva gikk jobben din ut på?}

- Jeg var visedirektør for prosjektet. Jeg skulle jobbe i skjæringspunktet mellom medisinsk fagkunnskap og administrative problemstillinger, ofte opp mot embetsmenn på høyt nivå i det indiske helsebyråkratiet. Jeg ble blant annet plutselig oppnevnt av det indiske helsedepartementet til en ekspertgruppe for nyfødtmedisin og en ekspertgruppe for mødre- og barnehelse som eneste ikke-inder. Det sier nok mer om prosjektets posisjon enn min posisjon. - Hva tenkte du da du ble spurt?

- Det føltes jo, sett fra mitt hjemlige ståsted, helt vanvittig og er på listen over mor- somme historier i mitt repertoar, selv om det selvfølgelig er en ære og ikke minst en mulighet til å påvirke og å lære. Det viser også hvor vanskelig det er å drive langsiktig arbeid i et slikt land. Jeg mener at det vi gjør som verdenssamfunn med utviklingshjelp kan underminere lokale myndigheters evne og mulighet til å bygge langsiktige systemer. Det er mange som har kommentert at et land som India, som har vært et stabilt demokrati i 60 år og som nå har en av verdens raskest voksende økonomier, egentlig ikke burde ha det hjelpebehovet det har. Landet har samtidig store ambisjoner. De har eget romfartsprogram og atomprogram, de lager jagerfly og biler. - Hvorfor greier de ikke å bygge sykehus når de kan drive romforskning?

- Jeg tror det har mye med likeverd å gjøre og at det er vanskelig å løse helseproblemene uten det i bunnen. Likeverd er noe vi nordmenn oppfatter som en universell sannhet. Slik er det ikke i India. Landet er medlem av FN og har underskrevet traktatene, men hvis man ser på hva som gjennomsyrer mentaliteten, så er det noe ganske annet. De med lav kaste og dårlig økonomi oppfattes som mindre verdt. Derfor dør fremdeles barn, selv i Delhi, av en banal lungebetennelse eller diaré. Det er fryktelig komplisert, selv om det jo på samme tid er ufattelig enkelt, nærmest banalt.

Han nærmest sukker.

- Provoserende for en sosialdemokratisk anlagt nordmann?

- Det er en diplomatisk måte å si det på. - Ble du opprørt?

- Jeg var mye sint, særlig i begynnelsen. Det ikke å kunne vise sterke følelser, selv om noe strider mot alt man tror på, er uvant for oss. Jeg måtte lære meg teknikker for å håndtere det, siden konflikt med dem som har beslutningsmakt ikke kommer noen til gode. - Hva var teknikken?

Han nøler med å røpe det og smiler.

- Den aller mest effektive teknikken min for å avreagere er å spille Playstation når jeg kommer hjem, gjerne et litt aggressivt spill. - Hva ble du mest sint over?

- Det som provoserer mest, er å se kolleger, som man automatisk har en slags legestandsrespekt for, rått utnytte fattige 
mennesker og stjele penger fra folk som nesten ikke har noe. Jeg ser ikke på det å være lege som bare et yrke, men som noe man er.

\section{Fra musikk til medisin}

- Du vurderte å bli musiker også?

- Jeg husker at dette var en debatt jeg hadde gående med meg selv fra ungdomsskolen. Jeg hadde lyst til å bli lege, men drev samtidig mye med musikk, og mange av vennene mine fra den tiden er musikere i dag. I tenårene drev jeg med musikk nærmest på heltid. Jeg gjorde spillejobber i stedet for mattelekser. Jeg tok mellomfag i musikkvitenskap og hadde lyst til å drive med komposisjon. På vei til mellomfaget skjønte jeg at det ikke var musikk som var fremtiden for meg profesjonelt.

- Hvordan skjønte du det?

- Jeg er ikke så glad i å øve på de samme tingene om igjen, det ødela litt av gleden ved musikken. Jeg ville heller ha musikk som hobby. Da ble det medisinstudier i stedet.

- Du beskrives som en som kan alt. Er du født slik eller blitt slik?

- Dette blir fort litt pretensiøst. Jeg tror jeg alltid har vært nysgjerrig. Jeg hadde tidlig en tanke om allsidighet som et mål i seg selv. Jeg har nok et sterkt konkurranseinstinkt, i alle fall sier andre det, og jeg har det aldri så bra som når jeg begynner på noe nytt. Hvis jeg ser på humørtoppene i livet mitt, så sammenfaller de ofte med nye prosjekter og det å være kastet ut i nye utfordringer.

- Er du en fullfører?

- Ferdigstillingsevne er min svakeste side, men jeg fullfører. Det tar bare ofte lengre tid enn jeg hadde tenkt. Jeg husker at faren min tidlig innprentet at jeg ikke måtte være en som bare begynte på ting uten å gjøre det ferdig.

- Du sier ja til mye, har du noen gang angret?
- Jeg har ikke så lett for å angre og reserverer det begrepet for de ordentlig dumme tingene jeg gjør. Nesten alltid når man hiver seg ut i store ting, kommer det en fase der alt er spennende og så en tung fase der man ikke får til noe. Det hender jeg føler at jeg må bli flinkere til på forhånd å tenke at det kommer slitsomme dager. Jeg har allikevel ingen store prosjekter jeg ikke har fullført. - Doktorgraden din?

- Det er åtte år som er det maksimale man kan bruke, er det ikke? Jeg ser en doktorgrad som et langt og avansert kurs i forskningsmetodikk og i det å bli kvalifisert til å drive med forskning. Jeg synes jeg er privilegert som får sette av tid til å fordype meg i noe. Jeg driver med forskning på hyperbilirubinemi hos nyfødte $\mathrm{i}$ en cellemodell.

\section{Til fjells i Afghanistan}

\section{- Hva skal du nå?}

- Akkurat nå har jeg ny jobb i forsvaret og skal til Afghanistan med et norsk bidrag. - Etter halvannet år i India, hvorfor skal du reise ut igjen?

- Jeg visste litt om oppdraget og jeg synes det virker som en riktig ting å gjøre. Det handler om mye av det samme som vi har gjort i India. Vi skal bistå landet med å få deres sikkerhetssystemer til å virke. Dette oppdraget gir mening. Vi er i en situasjon der Vesten har gått inn i Afghanistan. Nå må man finne en måte å trekke seg ut på som ikke gjør det verre enn det var. Det er selvfølgelig også en komponent av eventyrlyst. - Hva skal til for at det er verdt fraværet?

- Fraværet fra familien er det som er aller vanskeligst og også vanskeligst å forsvare. Han blir nesten litt stille for første gang i intervjuet.

- Er det noe du skulle ønske du hadde mer tid til?

- Jeg forsøker å prioritere det jeg føler er viktig. I og med at jeg har en tilbøyelighet til å ta på meg for mye, er løpende oppgave-

\section{Tomas Nordheim Alme}

\author{
Født 18. mai 1974
}

- Mellomfag i musikkvitenskap Universitetet i Oslo 1995

- Cand.med. Universitetet i Oslo 2003

- Lege i spesialisering, Sykehuset Buskerud 2005-06

- Styremedlem Norsk Barnelegeforening og redaktør i Paidos

- Stipendiat ved Pediatrisk forskningsinstitutt Rikshospitalet 2006 -

- Medisinsk rådgiver DIPS 2006 -

- Visedirektør Norway India Partnership Initiative 2009-10

- Lege i Forsvaret (ISAF) 2010 -

Foto Marit Tveito

prioritering noe jeg har en del erfaring med. Jeg kan se at det til tider kan være frustrerende for andre. Som mange andre foreldre føler jeg også fra tid til annen at jeg er for lite til stede for barna mine. Men vi er veldig tette, vi har alltid reist rundt sammen med barna og hatt dem med oss overalt. Signe og de tre gutta er de beste vennene mine.

- Er det noe jeg burde spørre deg om?

- Jeg er opptatt av legerollen, selv om jeg kanskje ikke er i posisjon til å ha noen kvalifisert mening om det, men jeg har sansen for allsidighet og det å være generalist. Det er et dilemma at vi ønsker å kunne tilby førsteklasses helsetjenester, nærmest gratis, $i$ et land der vi mangler pasientvolum til å rettferdiggjøre enkelte høyspesialiserte funksjoner. I kjernen av et velfungerende helsesystem er vi nødt til å ha allsidige og flinke generalister både i primærhelsetjeneste og på sykehus. Allsidighet har til alle tider vært en livsnødvendighet i store deler av landet vårt, og det gjenspeiler seg også i verdiene våre. Spesielt er jo vi nordmenn nærmest ytterliggående opphengt i praktiske ferdigheter. Det viser blant annet undersøkelser om hvilke egenskaper kvinner ser etter hos menn; det å ha god utdanning og jobb er i seg selv ikke nok. «Det er greit nok at du er lege, men er du handyman nok til å sette opp en vegg?»

\section{Marit Tveito}

marit.tveito@diakonsyk.no

Diakonhjemmet sykehus 